\title{
Utilization of Ficus benjamina by Birds at Urban Habitat in Depok
}

\author{
Dimas Haryo Pradana $a^{\mathrm{a}^{*}}$, Ani Mardiastutib ${ }^{\mathrm{b}}$, Masman $^{\mathrm{c}}$ \\ ${ }^{a}$ Department of Biology, Universitas Indonesia, Depok, Indonesia \\ *Corresponding author E-mail : d.h.pradana@ui.ac.id \\ ${ }^{b}$ Department of Forest Resources Conservation and Ecotourism, Bogor Agricultural University, Bogor, Indonesia \\ aniipb@indo.net.id \\ ${ }^{a}$ Department of Biology, Universitas Indonesia, Depok, Indonesia \\ yasman09@yahoo.com
}

\begin{abstract}
Most of the research about the relationship of birds and figs were conducted at natural habitat. We conducted a research about this relationship at urban habitat in Depok and specifically studied utilization of Ficus benjamina by birds as feeding and nesting tree. The objective of our research was to describe the $F$. benjamina utilization by urban birds in Depok. Scans sampling and nest counting were used during this study. Our research shows that $F$. benjamina was used as feeding tree by most of birds which lives at urban habitat in Depok. Our research also shows that some birds used this fig species as nesting tree.
\end{abstract}

Key Words : birds, Ficus benjamina, urban, Java

\section{INTRODUCTION}

Birds and figs (Ficus spp.) have mutualistic relationship. Birds disperse seeds of figs, while figs provides fruits for birds (Lok and Lee, 2009). The relationship between birds and figs has been studied by several scientists such as Lambert and Marshall (1991), Midya and Brahmachary (1991), Kinnaird et al. (1996), also Mardiastuti et al. (2000). Those research were mainly conducted at natural habitat

Ficus benjamina is one of figs species that usually can be found in several urban habitats in Java Island. This fig species can be found at Jakarta, Bogor (Arifin and Nakagoshi, 2011), Depok, Bandung (personal observation), and Yogyakarta (Nugroho et al., 2005).

Utilization of Ficus benjamina by urban birds as feeding tree was recorded by Lok and Lee (2009). Meanwhile, use of this fig species as nesting tree were recorded by Hilaluddin et al. (2003) and Nugroho et al. (2005). Those research were not specifically studied about utilization of $F$. benjamina by birds in urban habitat.

We conducted a research about the utilization of Ficus benjamina by birds at urban habitat. We used Universitas Indonesia Depok campus parks as a case study. The research questions of this study was: Do birds at urban habitat use this fig species as feeding and nesting tree?

\section{METHODS}

This research was conducted on 6 campus parks that existed in faculties and rectorate building of Universitas Indonesia Depok Campus from August to September 2009. Ficus benjamina only could be found in these 6 parks and each parks had different number of $F$. benjamina trees. Parks which had higher number of trees had higher number of sampling units, and vice versa. The number of $F$. benjamina tree which we observed were 12 trees.

Scans sampling method with 5 minutes interval (Muzaffar, 2004) and 12 numbers of interval (scan sample) was used for observing bird activities on Ficus benjamina trees between 06.00 and 08.00 a.m. and also between 15.30 and 17.30 p.m. The observations were aided by $10 \times 42 \mathrm{~mm}$ binocular. The activities that we observed were feeding, perching, and preening. We counted the percent of time (Altman, 1974) of each bird activity using this formula : 
$\%$ of i-activity $=$ (total number of scan samples in which i-activity observed/total number of scan samples) x $100 \%$

We compared the percent of time of feeding activity to other activities for each species. We excluded granivores and terrestrial birds from this analysis because they do not eat fruits or forage on trees. For utilization of $F$. benjamina as nesting tree data, we only counted number of nest on each sampling units i.e., $F$. benjamina trees, and included all birds we found during data collection.

\section{RESULTS AND DISCUSSION}

We found 14 bird species on Ficus benjamina and most of the species were insectivore, only 2 species that were frugivores i.e., Pycnonotus aurigaster and Dicaeum trochileum. Total of scan samples were 288 samples and the most common species that we observed during research was $P$. aurigaster, observed in 129 scan samples (Table 1). Bird species that we found were species which usually can be found in urban habitats. Those species also can be found in Jakarta (Kristanto and Momberg, 2008), Bogor, Bandung (personal observation), and Yogyakarta (Taufiqurrahman et al., 2015). This result may also describe the utilization of $F$. benjamina by birds in other urban habitats in Java Island. Indeed, further study is needed.
Table 1. Checklist of bird species that were observed on Ficus benjamina including the food they ate based on observation

\begin{tabular}{|c|c|c|c|}
\hline Famili & Scientific name & $\begin{array}{l}\text { Number } \\
\text { of scan } \\
\text { samples }^{\star *}\end{array}$ & $\begin{array}{l}\text { Type of } \\
\text { food }^{\star * *}\end{array}$ \\
\hline Columbidae & $\begin{array}{l}\text { Streptopelia } \\
\text { chinensis* }\end{array}$ & 1 & - \\
\hline Picidae & Picoides moluccensis & 2 & - \\
\hline Campephagidae & $\begin{array}{l}\text { Pericrocotus } \\
\text { cinnamomeus }\end{array}$ & 3 & 1 \\
\hline Chloropsidae & Aegithina tiphia & 6 & I \\
\hline Pariidae & Parus major & 1 & - \\
\hline Pycnonotidae & $\begin{array}{l}\text { Pycnonotus } \\
\text { aurigaster }\end{array}$ & 129 & I, F \\
\hline \multirow[t]{3}{*}{ Sylviidae } & Gerygone sulphurea & 14 & 1 \\
\hline & Orthotomus sutorius & 6 & 1 \\
\hline & O. sepium & 15 & $\mathrm{I}$ \\
\hline Nectarinidae & $\begin{array}{l}\text { Anthreptes } \\
\text { malacensis }\end{array}$ & 40 & 1 \\
\hline Dicaeidae & Dicaeum trochileum & 20 & - \\
\hline Zosteropidae & $\begin{array}{l}\text { Zosterops } \\
\text { palpebrosus }\end{array}$ & 9 & I \\
\hline \multirow[t]{2}{*}{ Ploceidae } & Lonchura punctulata* & 4 & - \\
\hline & Passer montanus* & 1 & - \\
\hline
\end{tabular}

*excluded from feeding activities analysis **total of scan samples in which each of bird species observed in scans sampling

***I: insects or other arthropods; F: Ficus benjamina fruit; - : feeding activity was not observed

From 11 bird species which we included in analysis, 7 species were observed feeding on Ficus benjamina and 3 of them had higher feeding activity than other activities (Table 2). Of those species, only $P$. aurigaster that was observed ate the fruit of $F$. benjamina (Table 1). Our result shows that $F$. benjamina was used as feeding tree by most of birds which lives at urban habitat in Depok. This finding shows the importance of $F$. benjamina for urban birds in Depok, especially as food source. In urban parks of Singapore, $F$. benjamina is also a food source for urban birds (Lok and Lee, 2009; Lok et al., 2013). On the contratry, this fig species was not a food source for urban birds in Hong Kong because it is not a native fig species (Corlett 2006).

$D$. trochileum did not observed feeding on $F$. benjamina (Table 2) because this species usually 
eats fruit of mistletoe (MacKinnon et al., 2000; Cheke and Mann, 2016). The mistletoe which we found on $3 F$. benjamina trees did not bears fruits. This flowerpecker probably also feeding on $F$. benjamina if there were mistletoe fruits. $D$. trochileum seem to have a preference for mistletoe fruits because other flowerpecker in Singapore urban area, Dicaeum cruentatum, has been observed feeding on F. benjamina fruit (Lok et al., 2013).

There were 3 insectivore that were not observed feeding on $F$. benjamina during scans sampling i.e., Zosterops palpebrosus, Parus major, and Picoides moluccensis (Table 2). Z. palpebrosus was observed ate insect on $F$. benjamina, but the observation was not during data collection. $P$. major probably also feeding on $F$. benjamina, but was not observed because the number of scan sample of this species was very low (Table 1). On the contrary, $P$. moluccensis most probably is not feeding on $F$. benjamina. According to MacKinnon et al. (2000), this woodpecker species usually feeding on dead trees.

Table 2. Mean percent of time of each activities

\begin{tabular}{|c|c|c|c|}
\hline Scientific name & $\begin{array}{l}\text { Feeding } \\
(\text { mean } \pm S D)\end{array}$ & $\begin{array}{l}\text { Perching } \\
\text { (mean } \pm S D)\end{array}$ & $\begin{array}{l}\text { Preening } \\
\text { (mean } \pm S D)\end{array}$ \\
\hline $\begin{array}{l}\text { Picoides } \\
\text { moluccensis }\end{array}$ & 0 & 100 & 0 \\
\hline
\end{tabular}

\begin{tabular}{|c|c|c|c|}
\hline $\begin{array}{l}\text { Pericrocotus } \\
\text { cinnamomeus }\end{array}$ & $50 \pm 70.71$ & $100 \pm 0$ & 0 \\
\hline
\end{tabular}

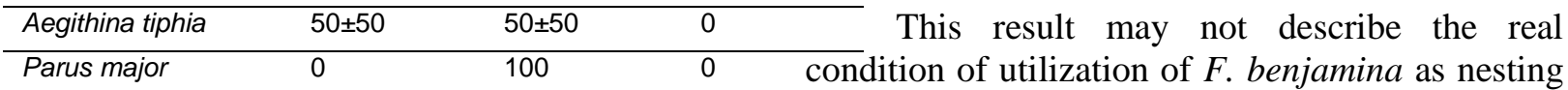

\begin{tabular}{lllll}
\hline Pycnonotus & $13.78 \pm 20.39$ & $86.22 \pm 20.39$ & 0 & tree. Birds in tropical region usually breeds in
\end{tabular}

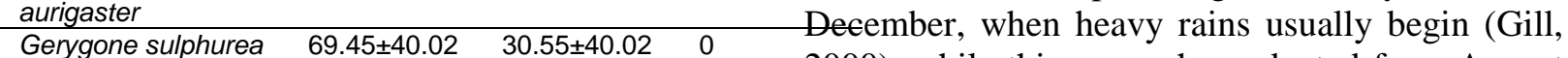
\begin{tabular}{llllll}
\hline Gerygone sulphurea & $69.45 \pm 40.02$ & $30.55 \pm 40.02$ & 0 & $2000)$, while this research conducted from August \\
\hline Orthotomus sutorius & $100 \pm 0$ & 0 & 0 & .
\end{tabular}

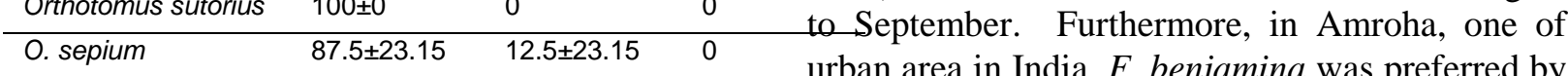
\begin{tabular}{lllr} 
Anthreptes & $36.33 \pm 41.68$ & $62.08 \pm 43.42$ & $1.59 \pm 4.7$ birds an area in India, $F$. benjamina was preferred by \\
\hline
\end{tabular}

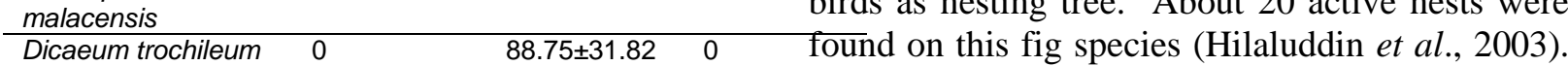

\begin{tabular}{lllll}
\hline Zosterops & 0 & $100 \pm 0$ & 0 & To know the real condition of this kind of
\end{tabular}
palpebrosus

We found one active nest, belonging to Zosterops palpebrosus, and 2 inactive nests on 3 different trees. The active nest of $Z$. palpebrosus was found on 27 August 2009. One of the two inactive nest had different structure with the nest of $Z$. palpebrosus, the inactive nest was a suspended nest (Figure 1) while the nest of Z. palpebrosus was a cup nest. The inactive nest probably was nest of sumbird (Bas van Balen communication). We concluded that there were at least 2 different species which build their nests on F. benjamina.

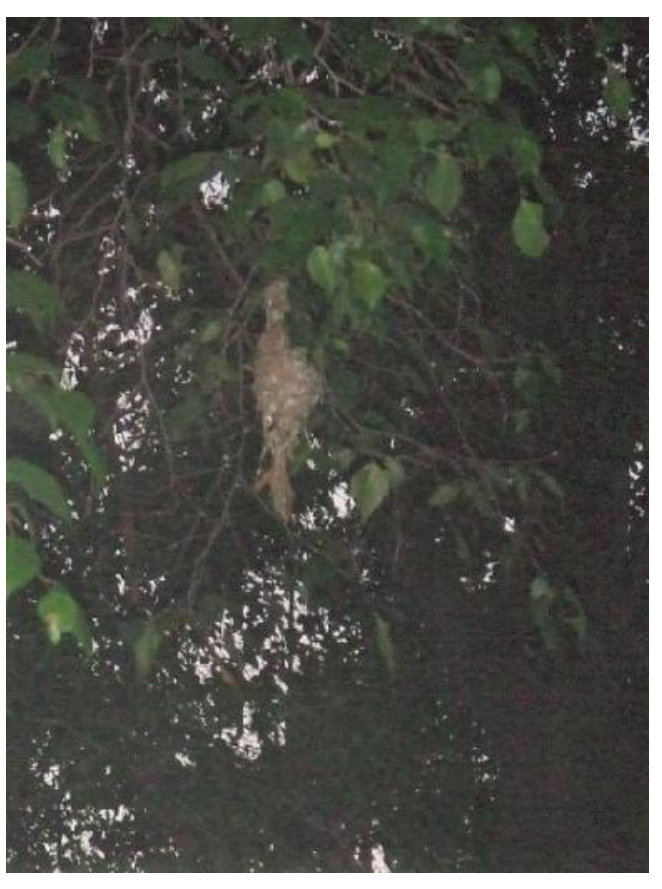

One of the inactive nest which was probably nest of sunbird utilization, further research has to be conducted in December.

\section{CONCLUSION}

Our study shows that most of birds which lives at urban habitat in Depok utilized Ficus benjamina as their feeding tree. This study also shows that some urban birds of Depok used $F$. 
benjamina as nesting tree, but this result may not describe the real condition and need a further study.

\section{ACKNOWLEDGMENT}

This paper is a part of paper which we presented at Seminar Ornitologi Indonesia dan Revitalisasi Perhimpunan Ornitolog Indonesia. We thank Dr. Adi Basukriadi and Dr. Nisyawati for their comments on the paper which we presented at that seminar. We also thank Dr. Bas van Balen and Dr. Karyadi Baskoro for their comments about the 2 inactive nests we found during our study. We also wish to thank an anonymous reviewer for the comments on the earlier version of this manuscript.

\section{REFERENCES}

Altmann, J. 1974. Observational study of behavior: Sampling methods. Behaviour 49: 227 - 267.

Arifin, H.S. and N. Nakagoshi. 2011. Landscape ecology and urban biodiversity in tropical Indonesian Cities. Landscape Ecological Engineering 7: 33 - 43.

Cheke, R. and C. Mann. 2016. Scarlet-headed Flowerpecker (Dicaeum trochileum). In: del Hoyo, J., Elliott, A., Sargatal, J., Christie, D.A. and de Juana, E. (eds.). Handbook of the Birds of the World Alive. Lynx Edicions, Barcelona.

Corlett, R.T. 2006. Figs (Ficus, Moraceae) in urban Hong Kong, South China. Biotropica 38(1): $116-121$.

Gill, F.B. 2000. Ornithology. W.H. Freeman and Company, New York.

Hilaluddin, J.N. Shah and T.A. Shawl. 2003. Nest site selection and breeding success by cattle egret and little egret in Amroha, Uttar Pradesh, India. Waterbirds 26(4): 444 - 448.

Kinnaird, M.F., T.G. O'Brien and S. Suryadi. 1996. Population fluctuation in Sulawesi RedKnobbed Hornbills: Tracking figs in space and time. The Auk 113(2):431 - 440.

Kristanto, A. and F. Momberg. 2008. Alam Jakarta: Panduan keanekaragaman hayati yang tersisa di Jakarta. PT Rajagrafindo Persada, Jakarta.
Lambert, F.R. and A.G. Marshall. 1991. Keystone characteristics of bird-dispersed Ficus in a Malaysian Lowland Rain Forest. The Journal of Ecology 79(3): 793 - 809.

Lok, A.F.S.L. and T.K. Lee. 2009. Barbets of Singapore part 2: Megalaima haemacephala indica Latham (Coppersmith barbet), Singapore's only native, urban barbet. Nature in Singapore 1: 47 - 54.

Lok, A.F.S.L, W. F. Ang, B. Y. Q. Ng, T. M. Leong, C. K. Yeo and H. T. W. Tan. 2013. Native Fig Species as a Keystone Resource for the Singapore Urban Environment. Raffles Museum of Biodiversity Research, Singapore.

MacKinnon, J., K. Phillipps, dan B. van Balen. 2000. Burung-burung di Sumatera, Jawa, Bali, dan Kalimantan (termasuk Sabah, Serawak dan Brunei Darusssalam). Puslitbang Biologi-LIPI, Bogor.

Mardiastuti, A., L.O.R. Salim and Y.A. Mulyani. 2000. Pemilihan tempat dan waktu mencari makan oleh satwa-satwa frugivora pada pohon Ficus di Suaka Margasatwa Lambusango, Buton. Biota 5(1): $22-28$.

Midya, S. and R.L. Brahmachary. 1991. The effect of birds upon germination of banyan (Ficus bengalensis) seeds. Journal of Tropical Ecology 7: 537 - 538.

Muzaffar, S.B. 2004. Diurnal time-activity budgets in wintering ferruginous pochard Aythya nyroca in Tanguar Haor, Bangladesh. Forktail 20: 25 - 27.

Nugroho, W., Djuwantoko and W.N. Jati. 2005. Studi perilaku teritorial burung cangak abu (Ardea cinerea Linn.) di Kebun Raya dan Kebun Binatang Gembiraloka Yogyakarta. Biota 10(3): 170 - 175.

Taufiqurrahman, I., I.P. Yuda, M. Untung, E.D. Atmaja and N.S. Budi. 2015. Daftar burung Daerah Istimewa Yogyakarta. Yayasan Kutilang Indonesia, Yogyakarta.. 